\title{
A NARRATIVE ON THE ORIGINS OF MANTRA IN THE BAJAU COMMUNITY OF PITAS, SABAH
}

\author{
(Naratif Asal Usul Mantera dalam Masyarakat Bajau \\ di Pitas, Sabah)
}

Jasman Bandar

fytazmanjasmanbinbandar@yahoo.com

Lokman Abdul Samad

lokns@yahoo.com

The Centre for the Promotion of Knowledge and Language Learning Universiti Malaysia Sabah.

Published online: 3 December 2018

To cite: Jasman Bandar and Lokman Abdul Samad. (2018). A narrative on the origins of mantra in the Bajau community of Pitas, Sabah. Malay Literature 31(2), 203 - 226.

\begin{abstract}
This qualitative study was intended to document and perceive the existing narratives on the origins of mantra among the Bajau community living in the villages of Kampung Mapan-Mapan Darat and Kampung Mapan-Mapan Laut in Pitas, Sabah. This study uses participant observation as a systematic method of collecting data on mantra through three informants, who are also experienced mantra practitioners, residing in the two said villages. The data collected was analyzed using Malinowski's functional theory, which emphasizes on analyzing the origins of occurrences and cultural phenomena in an ethnic group. This study focused more on the Bajau community's need for safety and food. The urgent documentation of the narrative of mantra is imperative before the practice disappears from the cultural expressions of the Bajau community.
\end{abstract}

Keywords: narrative, origins, mantra, Bajau community 


\begin{abstract}
Abstrak
Kajian ini dijalankan dengan menggunakan pendekatan kualitatif yang melibatkan proses temu bual serta pemerhatian sebagai cara untuk mendapatkan data kajian secara sistematik yang melibatkan tiga orang informan, di Kampung Mapan-Mapan Darat dan Kampung Mapan-Mapan Laut, Pitas. Dalam usaha untuk menganalisis data, penyelidik menggunakan kerangka teori fungsional Malinowsky yang menjurus kepada penganalisisan asal usul sesuatu kejadian dan fenomena budaya dalam sesuatu kelompok etnik. Penelitian ini lebih memfokuskan keperluan manusia dari sudut keselamatan dan keperluan terhadap makanan. Pada dasarnya, kajian ini dilakukan dalam usaha untuk meneliti naratifyang wujud untuk mengungkapkan asal usul mantera dalam kalangan masyarakat Bajau Pitas. Usaha pendokumentasian kajian naratif dalam mantera perlu dilakukan dengan segera sebelum warisan ini hilang daripada kamus budaya masyarakat Bajau Pitas.
\end{abstract}

Kata kunci: naratif, asal usul, mantera, masyarakat Bajau

\title{
INTRODUCTION
}

All human societies on earth have a narrative that describes the existence of their respective cultural imagery. The expression of such cultural imagery is meant as a strategy for a systematic and effective narrative, although it does not use the scientific approach fully in principle (Winstedt, 1961). Generally, this particular narrative element serves to reveal the circumstances and origins of the conception of an oral tradition (Wan Abdul Kadir, 2007; Hermansyah, 2010; Rosalyn, 2014). The foundation of a cultural background enables a society to believe in their creation myth. The meticulous scrutiny of each and every line of oral tradition corroborates their belief and understanding of past events. Tambiah (1968) and Noriah (2010) view that the influence of the current environment has created tales that reveal the factors and formation of mantra.

Human beings are capable of conjuring potent mantra to affect the lives of its community of practitioners (Herman, 1987; Walter \& Fridman, 2004; Azlina \& Yusmilayati, 2011). This practice was implemented by their forefathers to control and dominate their surroundings to benefit their livelihood (Asmah, 1987; Haron, 2000; Piris-P., Amahorseya, \& Pentury, 2000). Mohd Taib (1977) also supported this standpoint, believing that 
mantra shaped the customs and cultures of early societies, thus conserving the imagery that are directly connected to the environment.

The mantra found in Kampung Mapan-Mapan Laut and Kampung Mapan-Mapan Darat is an adaptation of the surroundings that chronicles all of their everyday experiences. The natural environment strongly influences and supports the process of creating mantra in these areas (Crick, 1976; Umar, 1981; Levi-Strauss, 1997). It is also discovered that mantra conjured in these villages discuss the development of their culture and lifestyle that is inherited through generations.

The precise origin of mantra in the past is unknown. The background of each mantra describes the chronological process of creating mantra within the society that practices them, even though it is not mentioned directly in the structure of the said mantra. Nevertheless, mantra explains the cultural background of a society through their display of symbols (Staal, 1990).

\section{RESEARCH PROBLEM AND SIGNIFICANCE}

The influence of mantra is diminishing in the lives of ethnic groups, consequently resulting in the extinction of their cultural heritage without preserving it for their future generation. This is reminiscent of the loss of past invaluable oral traditions that can never be regained in modern times. Thus, the documentation of the narratives regarding mantra must be done promptly before it ceases to exist with the passage of time.

This paper aims to become a pioneer study in mantra and other oral traditions as a method of preserving knowledge that will positively impact the documentation of oral tradition. It is hoped that this study will be exemplified by future researchers in their similar research endeavors. This study also aims to impart invaluable knowledge on local oral tradition to the general population as well as to effect the progress and advancement of traditional literature as a corpus of knowledge that is beneficial for modern society.

\section{MALINOWSKI FUNCTIONAL THEORY}

In order to produce credible research analysis and findings for this study, the researcher employed the Malinowski Functional Theory (1960). The Malinowski theory originated as a reaction towards evolutionary theory, and has laid the foundation for the development of social anthropology (Malinowski, 1939). According to Malinowski, the fulfillment of human social needs requires several factors in their lives to develop and progress 
peacefully and securely. Therefore, this theory is defined as a strategy to develop a more complex social system of living by focusing on the human social system based on the relationship of an individual, a group or a community. These relationships are indeed the foundation and the needs of human beings. Thus, the ideas generated in this theory become more valuable for studies on the development and benefits of the greater society. Bronisław Malinowski developed and established the conceptual study of the function of a social system. He asserted that the elements within a culture have functions that are connected with each other (Malinowski, 1922). Therefore, in conceiving this theory, he explained that the seven human physiological needs that must be fulfilled are metabolism (food \& drink), reproduction, bodily comfort, safety, movements, growth and health.

The seven basic human needs for survival can be divided into two categories: macrocosmos that reflects the tangible culture within a community and microcosmos that is more inclined towards the characteristics of a culture. Microcosmos basically underlies the context of psychological and biological needs.

In this study, the researcher only focused on the human needs of safety and food. This is because, based on the data collected by the researcher, it was found that both these needs are the most dominant requirements in the lives of the Bajau community. Therefore, it is not surprising that in the oral tradition, all the mantra presented emphasized more on these two factors that are essential for their survival.

\section{RESEARCH DESIGN AND METHODOLOGY}

This study applied qualitative research methodology, specifically the indepth and focused interview technique. Additionally, direct and indirect observations were made during the interview process with the participants in the field. This study relied on the following three informants who are also mantra practitioners:

1. Jamari bin Nasirin (68 years old), fisherman

Interviewed on March 5, 2018 at Kampung Mapan-Mapan, Pitas.

2. Muilling bin Usin (69 years old), fisherman

Interviewed on March 6, 2018 at Kampung Mapan-Mapan, Pitas.

3. Alai bin Taha (67 years old), fisherman

Interviewed on March 8, 2018 at Kampung Mapan-Mapan, Pitas. 
The above informants were selected for being the most active and experienced in mantra. This was due to the study's requirement for the informants to be able to effectively answer the research queries using subjective yet rational and logic evaluation. From the researcher's viewpoint, the informants interviewed were indeed vastly experienced in the subject of mantra, which facilitated the researcher's data collection of mantra materials required for later analysis.

The approximate population of the village is about 300 . However, the population invariably changes due to factors such as migration in search for better job prospects, education, economy, marriage or even a better life in another town. The villagers are of the opinion that the preservation or even practice of their oral tradition is no longer significant and worthy compared to the aspiration of a poverty-free livelihood. Nevertheless, from the researcher's viewpoint, this matter must be dealt with in a sensible and objective manner. It is understandable that the effort to gain success in the 21 st century should also incorporate upholding one's personal rights and values.

\section{AN ANALYSIS OF THE NARRATIVE ELEMENTS IN MANTRA IN KAMPUNG MAPAN-MAPAN DARAT AND KAMPUNG MAPAN-MAPAN LAUT IN PITAS, SABAH}

For the villagers of Kampung Mapan-Mapan Darat and Kampung MapanMapan Laut in Pitas, mantra displays exceptionally unique and superior characteristics. Since mantra comprises knowledge, the language used contains informal educational values that can be used and benefitted by people in experiencing a better and more meaningful life. Haron Daud (2001, p. 177) states:

The appliance of mantra can be seen through the cycle of life of a person, starting from the marriage of a couple. They recited the mantra to have a child, the fetus in the womb was "involved" with mantra and it continued until its birth. During its youth, adulthood and old age the person practiced mantra as an outfit and other things.

Based on the researcher's observation, it was found that a small group of villagers in the area still maintain mantra as a cultural legacy even though they do not wholly practice it. They are aware that if mantra is not preserved 
and ultimately abandoned, the future generation will not be able to trace and identify their traditional values. This is because their cultural identity is intrinsically structured within the recital of mantra, which was inherited from past generations. The evidence of mantra's superiority and high cultural values can be perceived through the following research findings.

\section{Occult and Mysticism}

Mantra that is themed on physical and spiritual strength is related to the history of the villagers of Kampung Mapan-Mapan Laut and Kampung Mapan-Mapan Darat resisting the invading British colonial forces. The bitter experience deeply affected the memory of the villagers. The British occupation caused them to rally for their freedom from the constraints of imperialism and suffering.

An informant narrated the anecdote of this mantra's origin; it started with a dream experienced by a rural, young and struggling man who decided to perform babar, which is a ritual ceremony intended to communicate with the spirits. Hence, the formation of this mantra reads as follows:

\section{Dua Tentera Deribu}

Bismillah hirahmaa nirrahim,

Aku masang dua tentera deribu,

Deribu tentara mengibang, deribu tentara maan kuanan,

Deribu tentara maan oropan, deribu tentera maan bukutan,

Aku moon rahmatnu, posokan duniya kami ta'duniya nu,

Selamatun jomo-jomo kami kok laat kami mendilaut,

Berkat laillaha illah Muhammad Rasullah.

[The Incantation of the Thousand Armies

In the name of Allah, the Beneficent, the Merciful,

I'm reciting the mantra of the thousand army,

A thousand armies on the left, a thousand armies on the right,

A thousand armies in front, a thousand armies at the back,

I pray for your mercy, enter our world into Your world,

Save the people and our place at sea,

Blessed by the grace that there is no other God but Allah, Muhammad is His messenger.]

(Source: Jamari bin Nasirin) 
The mantra above explains the lines recited by the practitioner. The lines were conveyed by believing and visualizing that there are a thousand armies on the left, a thousand armies on the right, a thousand armies in front and a thousand armies behind. Thus, no enemy was able to fight or disrupt their peace. This mantra was believed to have helped the Bajau community in Pitas from the infiltration of their enemies.

Initially, the migration of the Bajau community from Pulau Senanggil to other rural areas and villages such as Kampung Mapan-Mapan Laut and Kampung Mapan-Mapan Darat around Pitas was to find new settlements. They had endured defeat and casualties at the hands of the oppressive British and Japanese occupations. Due to migration, the long distance between their later settlements created many repercussions, among them being the loss of their original dialect. This disintegration led to the formation of various Bajau ethnic communities with their own dialects according to their region, which in turn symbolized their identity.

According to Jamari bin Nasirin, the Bajau community in Kampung Mapan-Mapan Darat and Kampung Mapan-Mapan Laut were very determined to find a way to fight and regain their autonomy. The long years of war against the colonizers caused heavy casualties and, without weapons, their population decreased with time. Despite the devastating circumstances and failure against colonial attacks, the villagers continued their struggle until the change of power from the British to the Japanese and again when the British regained their control.

Under the British and Japanese colonial rules, the villagers were made slaves or even massacred if they retaliated against the commands of the British or Japanese army. The years of enduring hardships incited them to retaliate against the cruelty and suppression of the British and later Japanese army. The oppression endured by the villagers pushed them to join forces and perform babar to protect themselves from all the challenges and trials they were encountering.

These experiences prompted the villagers to resolve their problems with great haste, as failing to do so will cause even more people to face suffering, terror, fear and also death. The oppression and pressures of life caused by war gave them the courage to do whatever was needed to fight for freedom in their surrounding villages. The problems faced by the villagers can be observed in the following dialogues: 
"Pein nu keluman kitai mitu, eko no jomo kitai matai, nyak beta' pupus tai man duniya tu." Eling urang tua sigaai.

["How can we continue on living, many of our people has died in the war, before long we will all be extinct from this world," said their chief.]

"Bah nyaun nu terati kami tu, amun matai matai noh nyaun harapan, lelai kitai tu laat emboh tai, nyak lelai kitai matai mitu.” Eling bujang delah meh oron ne Said.

["There is nothing more we can do. When death calls we will die. We move from this place. This is the home of our ancestors. If we remain here we will die," said the young man known as Said.]

“Bah pakat tai lumaan nu kam pinggu-pinggu mari kekuatan, peteko kam ta' pulau babar jo kam, maku kekuatan dan semimon alam. Gai penjajah boi ngerusak kedamaian tai mitu. Dokom negerusak laat ta alam tu." Eling urang tua sigaai.

["Together we agreed to roam and travel somewhere else to find strength, if you stop at an island, you just babar to plead for strength from the universe. The invaders or colonialist had damaged the peace and harmony of our lives. Just as they destroyed the earth," said their chief.]

(Source: Jamari bin Nasirin)

Some villagers went in secret to various places such as nearby islands and sought help from their ancestors. They performed babar and eventually attained extraordinary powers as a result of the composed verses of babar. They believed that the power or strength was gained from nature and the spirits existing in the natural environment that had united with them.

The existence of occult and mystical power is strengthened by berjin (meaning "with jinn") custom in Pulau Pinayu. The Bajau community were believed to have cooperated with the jinn to attack the colonizers. They used extraordinary and supernatural power with the help of the jinn and mystics. They also prayed to Allah for strength, a practice also followed by the jinn themselves. Thus, it is not surprising that most mantra invoke the name of Allah, the prophet and other angels or spirits in the verses. 
The rural Bajau community in Kampung Mapan-Mapan Laut and Kampung Mapan-Mapan Darat built a fort called Pulau Pinayu. The island comprised many armies, among them being the jinn, who were believed to have guarded the sea regions surrounding Kampung Mapan-Mapan Laut and Kampung Mapan-Mapan Darat. The Bajau community continued to faithfully respect and guard the areas around their villages. As a sign of respect, they prepared seven colored dishes such as pinjaram (a traditional cake), boiled chicken eggs, needles and flags to be sent to Pulau Pinayu as a symbol of their agreement and unity with the power of the jinn.

After a long period of fraternizing with the jinn and performing babar, a mantra was subsequently created, which contained magical power and supernatural strength. This mantra was believed to have the ability to enhance strength using mystical and magical power, to fight and resist the colonizers and pirates who wanted to conquer their regions.

A consequence of practicing babar led to the creation of the first mantra, "The Thousand Armies Mantra", which was believed to have the ability to summon all existing powers from the surrounding natural environmentsuch as the seas, hills, trees as well as the spirits of living creatures, both seen and unseen - to protect both the village areas and also fight enemies who intended to commit violence or robbery.

According to Jamari bin Nasirin, over time, the British returned and replaced the Japanese colonizers. The second British occupation caused anxiety among the Bajau community. Their apprehension resulted in the creation of mantra beyond the world (balik bumi). This mantra was used as a protective device when the British attacked from the sea. As a result, not only did the British fleet lost their way in the middle of the sea, but their vision blurred as soon as they reached the vicinity of the village areas of the Bajau community. Finally, the fleet were sunk by the crashing waves.

The war did not end here as the Bajau community also had to face further intimidation from pirates who, armed with sharp weapons, threatened to seize their territory. The pirates were brutal; they beheaded enemies and killed locals simply to achieve their purpose of securing strategic areas and new settlements. Kampung Mapan-Mapan Laut and Kampung Mapan-Mapan Darat were strategic regions that were sheltered from the wind, sea and the hills. These areas of strong fortresses were among the many reasons the pirates wished to make these villages as their transit and to carry out their activities. 
The pirates from the Philippines were known for their bravery in combat. Not only did they disturb the peace, but they also seized the livelihood of the Bajau community in Pitas. Faced with desperation and a small population, the Bajau community were forced to find ways to defeat the pirates.

The Bajau community's belief and practice of summoning the jinn (menteko jin) continued in Kampung Mapan-Mapan Laut and Kampung Mapan-Mapan Darat; the circumstances supported the creation of mantra in both villages. They believed that with assistance from the jinn and powers from their natural environment, they will be free from the ongoing assault and robbery.

The Bajau community in Kampung Mapan-Mapan Darat and Kampung Mapan-Mapan Laut of Pitas believed that their connection with the surrounding environment strengthened their ability to conjure mantra themed on magic and mystical power. This is because their lives were strongly influenced by the natural environment.

Subsequent to their conjuring of mantra themed on magic and mystical power, it is believed that no external colonial power and pirates have since attempted to disturb the peace and harmony of the villages for fear of the repercussions of the mantra and other practices performed by the villagers.

The new practice of summoning jinn (menteko jin) has currently spurred the evolution of mantra themed on magic and mystical power that has been in existence since past times. It is believed that Pulau Pinayu serves as the main fortress for the jinn to protect the peace and security of Kampung Mapan-Mapan Laut and Kampung Mapan-Mapan Darat from any ill-intended attack.

Nowadays, alongside its practices, the inception of mantra with magical and mystical power continues to be observed. The Bajau community's culture is manifested in the conservation of their sacred sites in various places, particularly the two sites of this study.

According to Jamari bin Nasirin, any person who enters these sites and breaches the taboos that has been set by their residents - either seen or unseen - will suffer from trouble and catastrophe. If the situation is not resolved immediately by making reparations to the jinn, the person will never be rid of this problem.

\section{Self Protection}

Self-protection mantra is associated with the existence of two spirits called pelerong and timbalun. It is believed that any person who is contacted or 
approached by these spirits will be inflicted, regardless of whether he is aware of their presence in the surrounding.

The presence of timbalun and pelerong is believed to expose their victims to sickness, misfortune and difficult encounters with predicaments. The continuous effects of these spirits can vary between a short and an extended period of time. An inflicted person can cease their effects by performing babar, which requires the assistance of a shaman who is skilled in the art of self protection.

The inflictions caused by timbalun and pelerong is not visible to the naked eye. It can only be known through dreams and the misfortunes encountered by their victim. The inflictions caused by these two spirits come in the form of a talisman (tangkal) or timbalun, which is shaped as a human and has an awful stench. The inflictions of this spirit are said to create difficulties for the affected victim.

Additionally, it is also believed that other people will cease to associate with the ill-fated victim. It is alleged that this is the result of pelerong or timbalun controlling the victim, causing him to meet with failed undertakings.

Pelerong is believed to originate from a roaming dead spirit that is seeking an abode and is reluctant to return to the grave. Pelerong usually latches onto a living person closest to them, be it the mother, father, siblings or closest friends. It is believed that pelerong occupies the body of their chosen living person, thus sometimes hindering the living person from moving freely even though they are capable of doing they want at will.

The Bajau community believe that pelerong exists when a person often dreams of someone who has long been dead, after which the said person will face misfortune. Timbalun, on the other hand, is believed to be caused by magic performed by humans to gain possession of something.

\section{Amun Tembuni Nyak Peluah}

[Bismillah hirrahman nirrahim,

Ngentan aku, ngentan was oros magat nuh,

Pongkou nou kou njata oron iblisnu,

Tinulak man alam $\mathrm{tu}$,

Pelaut njadi buek,

Berkat laillaha illah Muhammad Rasullah.

[If the placenta is held in

In the name of Allah, the Beneficent, the Merciful, 
Holding you, holding was your ghost's name,

Hey get up your devil's name,

A push from this earth,

To the sea crushed into water,

Blessed by the grace that there is no other God but Allah, Muhammad is His messenger.]

(Source: Muilling bin Usin)

The mantra above uses the appropriate words for curative purposes. Invoking the name of Allah, the shaman acted as the intermediary and pleaded with the spirit that was inflicting a pregnant woman with a retained placenta, complicating her labor. The shaman requested the spirit to return to its place of origin. The line, "a push from this earth", means that the grace of Allah will help expel the placenta without any complication. The line, "to the sea crushed into water", means that the guidance of Allah will enable all that is wished for to come as effortlessly as the flowing water.

The Bajau community in Kampung Mapan-Mapan Darat and Kampung Mapan-Mapan Laut also believe in the existence of Emboh, who is often deemed as the leader of the natural environment, be it the sea, hills, earth or other places. Therefore, the community seek help through the practice of babar, in which they harness energy from their surrounding natural environment through magical words in order to facilitate them with any undertaking.

Such practices have strengthened the Bajau community's belief in the power of the jinn, magic and other supernatural phenomena in order to gain something. Consequently, they are reaffirmed by the legitimacy of these beliefs since they were passed down by their ancestors. These practices were observed by the community in their daily life and, over time, they began to conjure spells or curse people they displeased. This act is known as numpahnumpah, which involves using derogatory words in a speech or curse on others and is believed to be approved by the surrounding existing elements.

Numpah-numpah is believed to have originated from an incident that happened amongst the Bajau community. It was told that someone related his misfortunes to an old village chief; his life was often hapless and all his ventured never succeeded. Thus, he was always anguished, which caused him to lose interest in any work. This predicament did not affect him alone but also the young men and women in his village. 
"Pien tu pak. Un joh masalah teko ta'kami semimon bujang. Un joh masalah ai mutung laan kami kerejo. Amun kami bedagang nyaun joh jomo meli. Amun kami pedilaut ngambur daing kok mukat. Dekiit joh tekulek kami, pein no mengkelum endo kok anak kami tu. Maku tulung kami tu bana-bana." Embara orang-orang Kampung delah ei ta'urang tua.

["How do we solve the predicament we are going through? There will always be problems hindering the performance of our work, if we are in business there is no clients. If we go fishing we are always hapless. Sometimes we only managed a few catch, how can we provide for our survival. We really need help," said the villager.]

"Bah, pien lagi, memiah noh kitai somo-somo ikhtiar supaya masalah tu nyaun lagi." Eling jomo tooh iei ai bingung.

["What can we do, let's work together to find a way out," said the old man confused.]

(Source: Muilling bin Esin)

Muilling bin Esin opined that pelerong and timbalun was behind the many problems that transpired in the village. The villagers often tried to usurp one another, causing strong disputes and hostility among themselves. Married couples experienced marital breakdown while those in love ended their relationships. In business, those who were successful were targeted with downfall by the envious. Ultimately, these issues led to the vulnerability of the peace and welfare of the village.

The cause of the above misfortunes was believed to be a group of people who were controlled by timbalun and pelerong to inflict others. Consequently, the villagers strained to find verses and conjure a spell on timbalun and pelerong in order to contact them through dreams or relay to the others via water, air and earth. It was told that one day, a few village elders approached the jinn's hermitage to seek resolution for their problems. The elders, being overly concerned about their people, experienced dreams in which they witnessed pelerong and timbalun frequently harassing someone, causing the latter's failure in everything that he desired or attempted.

Another incident involved a man named Said. He was the son of Jaha, who was the village chief of both Kampung Mapan-Mapan Laut and Kampung Mapan-Mapan Darat. Said strived hard to find a solution to 
overcome the misfortunes of his people. Thus, he began to perform babar as well as a ritual ceremony of returning the curse to its original source called empolek sumpah as an initiative to unite the people. The community believed that they were inflicted with edema as a repercussion of their wrongdoing.

Requests were made and a feast was offered to all the jinn and spirits from the surrounding environment; in turn, the unseen beings pledged to fulfil the demands of the villagers. The villagers then listed down all the verses representing each problem encountered using alphabet that they learnt from the jinn. After the hearing at the said event (the custom of stating the root of a story), all the spirits, jinn and other unseen beings agreed to never harass any person if the verses they have heard were chanted. If any of the unseen beings were to break their promise, misfortune and calamity will befall them.

According to Muilling bin Esin, since then, the villagers lived in peace. Every afflicted person was treated and a few reputable persons were taught to read the mantra that was handed down by their chiefs. However, the process of selection was believed to be done by four jinn, namely Israfil, Izrail, Mikael and Jibril. All four jinn scrutinized whether the chosen candidate was capable of upholding the occult with care and possessed similarities with them. If not, the candidate was not granted any spiritual power.

At long last, the lives of the people in both villages became peaceful and there was no more recurrences of misfortunes. They employed the mantra recited and practiced by skilled practitioners. The existence of jinn was acknowledged by developing a dwelling area for them, known as tamanggung, which is a place of assembly for all existing jinn. Tamanggung further validates the origins of the creation of local mantra in more detail.

\section{Making a Living}

The Bajau community believed that the sustenance of a person depends on the concept of nasipan and jerikian. This concept clarifies that diligent effort directly constitutes a person's prosperity. The Bajau community believed that people are neither guaranteed success with effort nor fulfillment through desire.

A Mantra on Making a Living

Manggil Jeriki

Bismillah hirahman nirrahim, Alam tara kaifa fa' ala, 
Kakaiku si kakai manuk,

Kakai kakai amun nyak kenakai nyaun no rezeki nei,

Berkat laillaha illah Muhammad Rasullah.

[Calling for the Providence

In the name of Allah, the Beneficent, the Merciful,

Have you not seen how ..., (from Arabic)

My scratch is the chicken scratch,

Without scratching there will be no provision,

Blessed by the grace that there is no other God but Allah, Muhammad is His messenger.]

(Source: Alai bin Taha)

The mantra above serves to facilitate and assist the Bajau community with their daily chores as well as to provide them with providence. The idea behind this mantra came from the behavior of chickens. Chickens are the symbol of tenacity; they usually rise at dawn to search for food by scratching into the earth. Although it does not appear at first, the chickens persistently scratch the earth until they find food. Scratching signifies the effort to procure something. The Bajau community believe that this insight from chickens taught them to be more diligent; they also learnt to rise in the early morning and go to sea, which best suited their fishing-related economy. Hence, this mantra influenced the Bajau community completely. It eases a person's job because by chanting the mantra, the person will gain the tenacity to work hard and achieve extraordinary strength. The person is even capable of working for an extended period of time in a day as compared to someone who does not chant the mantra.

The Bajau community believe that all living things have badi, which refers to the presence of a different essence in the human body. Mantra is believed to help expel badi from inflicting a person. Once the badi is released, the person is able to make a living anywhere without having to suffer any unwanted problems. Each mantra concerning the economy is believed to serve two roles, which are to assist in finding provisions and to prevent any disaster or misfortune. One disaster that is frequently faced by the Bajau fishermen is known as ai palit, or being lost at sea and unable to find the way home. They believed that only mantra can unravel the problem.

According to Alai bin Taha, nasipan refers to the ability of an abled and talented person to use his intellect and skills to perform any job and achieve 
what he wants. For example, if a person wants to fish, he must have adequate knowledge and skills of fishing that will result in a big yield. Additionally, it is believed that the nasipan of each person differs. With regard to the birth order of siblings, usually the middle child has more nasipan than the other siblings because it is the middle child who significantly contributes toward the betterment of the family's economy.

However, sometimes nasipan also depends on a person's tenacity and attribute to accomplish something to the best of his ability. Therefore, it is not solely based on one's birth order but also on the person itself. The Bajau community believe that a person with bad nasipan must summon nasipan from the environment to merge with him so that he can best improve his sustenance.

Jerikian is associated with any device used to achieve something, specifically a larger amount of yield. Years ago, the Bajau community used vehicles such as boats to secure a big catch at sea. Thus, the community claimed that the boat causes jerikian. If the reverse occurs and the fisherman does not secure what he intended, he will exchange his boat for another or build a new boat in order to increase jerikian.

When it comes to livelihood, jerikian is not only associated with objects but also with co-workers. The Bajau community believe that if the auras of co-workers conflict with each other, it can result in them yielding little sustenance. A person with less jerikian must cooperate with a person with more jerikian.

The Bajau community believe that a person must attempt to gain the aura of jerikian through babar with the natural environment. Babar is performed to summon the spirit of fortune that exists in the surrounding. They also believe that a person cannot simply wish for something as it may also be the wish of a spirit, albeit in a different context. This is apparent when the unseen supernatural beings in the surrounding also require food and energy for sustenance.

Stories concerning nasipan and jerikian are found in the folklore of the Bajau community in Kampung Mapan-Mapan Laut and Kampung Mapan-Mapan Darat in Pitas. The folklore further strengthens their belief regarding the conception of mantra for making a living. It is believed that long ago, the fishermen of Kampung Mapan-Mapan Laut and Kampung Mapan-Mapan Darat worked endlessly for their livelihood. Their poor and humble conditions caused them to rely on the sea and they bartered their 
catch for other produce such as tapioca, corn and bananas with the hills dwellers. During this time, their staple food was not rice but tapioca, such as putu (steamed tapioca). They also consumed finely grounded corn, known as buas gandum, which is cooked and eaten like rice.

According to Alai bin Taha, the Bajau community believe that the nasipan and jerikian of humans undergo a cycle of changes, just as the rotation of a wheel. This was evident when the fishermen did not always yield a good catch as it depends on the season. As a consequence, they faced difficulty in continuously striving to catch enough fish, which only increased their suffering. This situation worsened with decreasing yield, forcing them to be frugal, or kupun. They had to eat sparingly and just enough to survive. The sitaution continued year after year, forcing them to remain kupun in their daily lives. Kupun causes suffering because of their severely limited sustenance, and this situation both directly and indirectly dampened their spirit and stamina.

"Amun begae joh sumur matai noh kitai nyak mangan, landu bana ko aseh aseh keluman tai tu." Eling rayat ta'kampung eh.

[If the condition continues we will have problems to acquire food. What a pathetic life," said the villagers.]

'Dong noh kou begae susa atainu. Begae nu elum ta' duniya tu un sanang kok un susa pan. Dong noh kou ngerampus begae, sukur noh kou ai lagi kitai elum menduniya tu." Eling sehe nei.

["Do not be depressed. This is how life is in this world there is ups and downs, do not moan, you should be thankful that you are still being given the chance to live. This is the destiny of life in this world," said his friend.]

“Amun begae no, pien kita mari mangan.” Eling ni pelibu.

["In that is the case, how can we make a living," replied his friend.]

"Sabar tek kou engko un Nasipan kok Jerikian kitai lagi tu. Bah maku dua nu kau ta duniya tu supaya un laan ben keluman kitai tu sekemon." Eling sehe nei. 
["You must be patient, maybe there is still no nasipan and jerikian for us yet. Now in this world we just need to pray so that there is some mean for solution and convenience for our living," explained his friend.]

(Source: Alai bin Taha)

After a prolonged period of unresolvable problems, they became close to surrender. Yet, they continued on with their normal lives for this was the way they could go on. They were advised to constantly perform babar in order to enhance their jerikian and nasipan.

A young fisherman always performed babar to request for sustenance, and the spirit of fortune from his surrounding came to his aid to help yield a large catch. Even then, the fisherman often failed, but he persisted in his effort by building new boats and even performed babar at sea. Soon, he managed to catch a large amount of fish. Whenever he went to sea, he always returned with a good yield, be it in pools, capes or any other place. The following day, the young fisherman returned to the sea and, just as the previous days, he still managed to yield many fish. The villagers were astounded and decided to learn from him the techniques of obtaining a good catch at sea.

“Peien kou kolek daing ei. Eko bana jeriki nu.” Eling jomo kampung.

[“How do you managed to catch so much fish?" asked the villagers.]

"Aku nut tuturan embok ku, embara nei maku, muat kou biduk kok babar ko. Amun un nasip nu bah ei noh Jerikian." Yok delah eh.

["I followed the advice of my ancestors, they told me, while making a boat you have to babar, if you are fortunate that is your subsistence being compatible with the boat," said the youth.]

"Ai bana sab eh. Tekitoku kou joh eko bana tekulek ni amun kau pedilaut." Eling jomo kampung eh.

["Yes, that is correct. I am convinced, looking at what you managed to catch when you go to the sea," said the villagers]

(Source: Alai bin Taha) 
As a result, all the villagers believed in jerikian; they built new boats and performed babar as instructed by the young fisherman. Finally, after numerous trials and continuous observations, they too eventually thrived in catching more fish and became skilled in the art of fishing.

During this same period, unbeknownst to them, there were also other villagers who performed babar and managed to yield a good catch without having to change their boats or seek the aid of spirits. This occurrence made the fishermen question their chief.

"Ienkah arti nei dangan ei, jomo muat biduk kok babar ioh un pan eko jeriki nei. Un lagi dangan tu kok sehe nei un jeriki nei nyak nukar biduk. Leing gai ta' rang tua ei..” Eling jomo kampung.

["What does it mean if someone build a boat and perform babar and gets a large catch. And another goes to sea with a companion and do babar but without building a new boat yet also gets a large yield," said the villager.]

"Ei maksud nei eh no jerikian nei yang muat ko makai bagung bahau. Jerikian nei ta' bagung ei. Yang un sehe ei Jerikian nei ta sehe nei ai un aura gai muat jeriki rajin teko ta' gai." Eling urang tua ei.

["That means his jerikian is destined from the boat that he has built. Getting a large takings with his companion is the jerikian destined with his companion. The auras surrounding them," said the village chief.)

"Begae ka. Un lagi dangan tu nyak sadaran kami boh nit u terati kami, sebetah tu ioh dangan-dangan pedilaut nyak muat bagung bahau kok nyaun sehe nei pedi laut eko pan tekulekni mensari. Ien arti nei apak." Eling dangan lagi jomo.

["Oh, is that so? There is another thing that we have never known, but have just known. There is a Bajau youth who gets a good catch by not having to make a new boat and no companion to sea. What does it means," asked the other villager.]

"Aku elum mitu ai nu betah laman keluman emboh bi lagi aku ngendah ta moto ku kok ta' atai ku. Arti nei jomo ei nasipan bana. Numbur ganjil dokom dekau, telu limau, nasipan nei langah. Tapi un pan lain-lain ei un nasipan didirian nei. Betiru tu babar jih kam. 
Maku dua supaya kam kulek jeriki kok nasipan langah maan roh jeriki ta'alam tu." Eling urang tua ei.

["I have lived for a long time, ever since your grand parents' days I have observed with my eyes and heart. Odd numbers like one, three, five have high nasipan. There are also others of different numbers that have high nasipan. It all depends on the forces of nature. So, just by doing babar you will always be asking for help for more sustenance. Hoping that the spirit of fortune comes to you," said the elder.]

\section{(Source: Alai bin Taha)}

After some time, the mantra on making a living was conceptualized from the idea of nasipan and jerikian. According to the informant, the first mantra associated with sustenance is called kakai manuk, which was inspired by someone who was looking for seashells on the beach and found a large collection by scraping through the mud and retrieving shells from the sand.

Nasipan and jerikian is a cultural concept connected to the beliefs of the local community with regard to a person's sustenance. It is believed that the concept must be manifested through the practice of babar.

\section{FINDINGS}

Based on the findings of the field study made by the researcher, it is found that, undeniably, the two basic needs of life - safety and food - essentially prompted the conception of the Bajau community's mantra.

There are two contexts for conjuring mantra for safety using occult and mysticism; firstly, it is to safeguard from the harassment of intruders; and secondly, it is to safeguard from the harassment of supernatural beings that are inclined to create misfortune in their surroundings.

In the context of physical harassment from intruders, such as the British occupation, as well as to safeguard themselves, the Bajau community conjured mantra with the help of magical power as an alternative form of protection. It was used as a method of defense against the invading colonizers, who were using deadly weapons against the villagers. As an additional measure, the villagers also invoked mantra to preserve their lives against fatal conflicts. According to the statements made in the research findings, the researcher found that those who believed in the power of mantra were able to attain supernatural powers and retaliate the colonizers who were 
threatening their livelihood, safety and sovereignty. The villagers would not have been able to progress with their lives and social activities in peace if the above crisis remained unresolved.

Upon analysis using the Malinowski Functional Theory, it is established that safety is a human need that initiates cultural behavior by conceptualizing a traditional practice to safeguard oneself. This enables the community to perform all social activities needed for survival.

Similarly, safety is also needed to safeguard the villagers from disturbances by supernatural beings. This problem is much more complicated, which is why they believe that only with the formulation of specific mantra their continual problems can be resolved.

In order for the Bajau community to make a living, the recitation of mantra is believed to provide smooth-running assistance in all aspects of their jobs as well as all other activities performed by the community, including infrastructure building, fishing, agriculture and social activities, among others. In his book, Mantera Melayu, Haron (2000, p. 157) states that:

Apart from farming and hunting, there are many other jobs the Malays do, such as craftsmanship, trading and ore mining. In craftsmanship they build houses, boats and forge weapons, among others. The people are very meticulous when building something such as houses. The shaman is requested to choose the site for the house because it is believed that there are good and bad locations depending on the position of the land, type and the smell. It is alarming if the location is where the jinn reside or their route. As a precaution, the shaman recites the mantra.

The above statement supports mantra being used as a device by the Malay community in their work. The same applies to the Bajau community; mantra motivates them to perform any task as they believe they will not encounter any trouble and difficulty (Strauss, Claude Levi, 1997).

In context of making a living, the Bajau community believe in the existence of nasipan and jerikian. However, both nasipan and jerikian varies in each person. Thus, mantra is required to help people reach their height of nasipan and jerikian as well as for them to be relieved of perpetual poverty.

When analyzed using the Malinowski theory, the concept of nasipan and jerikian refers to the need for food to survive. As previously discussed, the researcher found that nasipan and jerikian are essential in the lives of 
the Bajau community in order to get enough sustenance for the survival of each and every member of their community. Without nasipan and jerikian, they believe that their quality of life will deteriorate and they will not obtain enough sustenance to make ends meet.

The lesson and knowledge regarding nasipan and jerikian is actually based on the beliefs of the traditional people regarding the animistic forces that exist in their surrounding natural environment that can assist in their effort to find sustenance. Thus, a person should supplement his action with the recitation of mantra in order to summon and request assistance from any supernatural being that is willing to aid in providing his livelihood.

\section{CONCLUSION}

As a conclusion, the study has documented the practice of selected mantra as detailed by three experienced informants. When analyzed against the framework of the Malinowski functional theory, it is learned that the role of mantra is very significant in the lives of the Bajau community. The conception of mantra is supported by their narratives that have been preserved across generations. Specifically, within each type of mantra, the origins of its existence is described in the form of a story and a main context. Through this, one is able to examine the development of culture that ensues due to the need for food and security. These factors inspired the conception of mantra in the lives of the Bajau community of Kampung Mapan-Mapan Darat and Kampung Mapan-Mapan Laut in Pitas, Sabah. The progression of mantra that arose in these regions generated several changes to the community. Mantra became a practice in the lives of the Bajau community for security, livelihood and social activities. Although nowadays this tradition is gradually being abandoned by its people, the task of documenting such traditions must be done promptly so that they will not disappear and, instead, remain as a legacy for future generations. 


\section{REFERENCES}

Alai bin Taha. (2018, March 8). Personal interview.

Asmah Haji Omar. (1987). Malay in its sociocultural contexts. Kuala Lumpur: Dewan Bahasa dan Pustaka.

Azlina Musa \& Yusmilayati Yunos. (2011). Simptom-simptom penyakit dalam main teri: Satu kajian kes di Kampung Pasir Mas Kelantan. Jurnal Melayu 8 , pp. $233-249$.

Bronislaw Malinowski (1922). Argonauts of the Western Pacific. London: George Routledge and Sons Limited.

Bronislaw Malinowski (1939). The group and the individual in functional analysis. American Journal of Sociology 44 (6), pp. 938 - 964.

Bronislaw Malinowski. (1960). A scientific theory of culture and other essays. New York: Oxford University Press.

Crick, M. (1976). Explorations in language and meaning. London: Malaby Press. Haron Daud. (2000). Mantera Melayu: Analisis pemikiran. Penang: Penerbit Universiti Sains Malaysia.

Haron Daud. (2009). Mantera dan unsur luar biasa dalam masyarakat Melayu. Penang: Penerbit Universiti Sains Malaysia.

Herman J. Waluyo. (1987). Teori dan apresiasi puisi. Jakarta: Penerbit Erlangga. Hermansyah. (2010). Ilmu Gaib di Kalimantan Barat. Jakarta: Kepustakaan Populer Gramedia.

Jamari bin Nasirin, B. (2018, March 5). Personal Interview.

Mohd Taib Osman. (1977). PerBomoan: Satu aspek world view dalam budaya Melayu dalam Zainal Kling (ed.). Masyarakat Melayu: Antara Tradisi dan Perubahan. Kuala Lumpur: Utusan.

Muilling bin Usin. (2018, March 6). Personal Interview.

Noriah Taslim. (2010). Lisan dan tulisan: Teks dan budaya. Kuala Lumpur:

Dewan Bahasa dan Pustaka.

Rosalyn Gelunu. (2014). Rinait: Bahasa keramat masyarakat Dusunik. Dalam Rahimah A. Hamid, Ahmad Moghni Salbani and Saad Othman (eds.) Merekayasa kearifan tempatan melalui bahasa. Pulau Pinang: Penerbit Universiti Sains Malaysia pp. 37 - 57.

Strauss, Claude Levi. (1997). Mitos, dukun, dan sihir. Yogyakarta : Penerbit Kanisius.

Staal, Frits. (1990). Ritual and mantras: Rules without meaning. New Delhi: Motilal Banarsidass Publishers.

Walter, Mariko Namba and Fridman, Eva Jane Neumann. (2004). Shamanism: An encyclopedia of world beliefs, practices, and culture. Volume 1. Santa Barbara, California: ABC-CLIO, Inc. 
Tambiah, S. J. (1968). The magical power of words. Man 3/2:175-208. 1990, magic, science, religion, and the scope of rationality. Cambridge: Cambridge University Press.

Wan Abdul Kadir Wan Yusoff, (2007). Mantera, budaya dan pemikiran orang Melayu. Kuala Lumpur: Dewan Bahasa dan Pustaka.

W. Piris-P., D. Amahorseya and J. Pentury. (2000). Sastra lisan Ternate: Analisis struktur dan nilai budaya. Jakarta: Departemen Pendidikan Nasional.

Winstedt, Richard. (1961). The Malay magician. New York: Oxford University Press.

Umar Yunus. (1981). Mitos dan Komunikasi Jakarta: Sinar Harapan.

Received: 3 Oktober 2018

Accepted: 22 November 2018 